\title{
Study of anxiety and fear level in dental practitioners from coronavirus and need of clinical practice modification to combat Covid -19
}

\begin{abstract}
An outbreak of novel corona virus (COVID-19) in China has influenced several aspects of the life of healthcare professionals, especially dentists, who are actually exposed to a higher risk of getting infected due to close interaction with their patients during treatments.

The study was conducted to understand the anxiety and fear level of dental practitioners in getting infected during practice in the current corona virus (COVID-19) situation. In addition, also to evaluate their awareness about various practice modifications needed or required to combat COVID-19 during clinical practice.

A cross-sectional study was conducted by an online survey from 3rd Aug to 8th Sept 2020. For the central region, a well-defined survey was planned at Google doc. A total of 239 participants from 16 different states of India had responded. Post scrutiny, completed questionnaires $(n=$ 210) were included in the study. Statistical analysis was performed using SPSS version 25. Chi-Square and tests were applied

The fear and anxiety levels of dentists are found as; $69 \%$ of participants were afraid getting infected from a patient visiting their clinics. $74.8 \%$ were scared while providing treatment to patients. $47.1 \%$ felt suggest or think not to do practice until the number of COVID-19 patient cases decreases. $54.3 \%$ participants felt anxiety and scared while interacting to patients while treatments, $81 \%$ have fear to carry the infection from clinic to their home and can get their family infected. $40 \%$ were afraid of getting quarantined and $59.5 \%$ were concerned about the cost of treatment on the off chance if get Infected. Dental practitioners are in a state of anxiety and fear while treating their patients due to the pandemic impact around the community. Anumber of dental practitioners have either modified their clinical practice process as per recommended guidelines for emergency treatment only, or closed down clinics for an uncertain period.
\end{abstract}

Keywords: Covid-19, Dental Practitioner, Corona virus, Pandemic

\section{Introduction:}

A novel Covid outbreak (COVID-19) in China has affected each part of life around. In last couple of months, corona has spread worldwide and on March 11, 2020, the World Health Organization (WHO) proclaimed it as a controllable pandemic disease[2,3]. The origin of Covid-19 is accepted to spread from a fish and marine food market in Wuhan, China1. On 11 February, 2020, WHO utilized the term COVID-19 to portray the strain of Covid4 19. Basically, COVID-19 is a ssRNA, encompassed infection with a size of $\sim 350$ kilo basepair (kbp5) . This virus cause serious respiratory tract infection among people and easily can transmit from individual to individual by means of hands, salivation, nasal beads, and surface contacts[3,6].

\begin{tabular}{|l|l|}
\hline \multicolumn{2}{|c|}{ Access this article online } \\
\hline \multirow{2}{*}{$\begin{array}{l}\text { Website: } \\
\text { www.ujds.in }\end{array}$} & Quick Response Code \\
\hline $\begin{array}{l}\text { DOI: } \\
\text { https://doi.org/10.21276/ujds.2020.6.3.24 }\end{array}$ \\
\hline
\end{tabular}

The normal hatching time frame scopes of COVID-19 from 4 to 14 days[7]. The impacted individual generally presents with upper respiratory tract infection (RTI) and protests of highgrade fever, a dry hack, and dyspnea8. It is highly recommended to keep any suspected individuals in quarantine

\begin{abstract}
${ }^{1}$ BHARAT, R., ${ }^{2}$ JAGNADE, R., ${ }^{3}$ KATARE , G., ${ }^{4}$ DAGA, $S$. ${ }^{1}$ Dept of Orthodontics and Dentofacial Orthopedics Index College of Dental Sciences, Indore

${ }^{2}$ Dept of Periodontics Index College of Dental Sciences, Indore

${ }^{3}$ District Hospital Dewas

${ }^{4}$ Department of Conservative Dentistry and Endodontic College of Dentistry, Indore
\end{abstract}

\section{Address for Correspondance :Dr Rakhi Bharat G-1 Akshat Regency ,106 Geeta Nagar Indore , M.P. (email - drrakhie@gmail.com)}

Received : 21 Sep. 2020, Published : 31 Dec. 2020 
(isolation) and under observation until further investigation by the real-time polymerase chain reaction (RT-PCR) can take place9, unfortunately, there is no antiviral immunization available, yet on 16th March 2020 the main clinical preliminary was started by the National Health Institute (NHI), USA[3]. Thusly, patients need to depend on steady treatment, for example, nutrients $\mathrm{A}, \mathrm{C}$ and D10 chloroquine phosphate; and general medical care until the body's resistant framework can restrict the disease to spread more robust in the body and transmitted to people who are living together.

Thinking about the imperative part of the body's invulnerable framework, older patients with interminable weakening ailments have a higher danger of getting contaminated contrasted with youthful, young healthy people with a good immune system resistant body framework. In spite of the fact that the mortality related with COVID-19 is low, it has a high spreading potential. Since the COVID-19 outbreak is so quick and destroying, numerous nations have closed down. Medical services experts are presented to a higher danger of getting tainted because of their nearby contact with contaminated patients.

Specifically, dental specialists play out their obligations in close contact with patients as well as while presented to vaporized aerosols and beads sprinkling out of patients' while doing oral treatments. Hence, dental practitioners have a high danger of getting infected from patients and can conceive spreading it to their companions, families, and different patients. Under these conditions, it's obvious for dental doctors to build up a threat, anxiety or fear of being infected by their patients. Fear and nervousness are incredible feelings that might be related with the staggering reports on the COVID-19 pandemic by social, electronic, and print media. Dental specialists got serious uneasiness by the current pandemic circumstance having threat of getting infected while treating their patients being in close interaction due to oral 1 treatment procedures.

Thinking about the current spread of contamination, the Indian Dental Association (IDA) featured key steps for safety to be taken by dental specialists, for example, taking patients' ongoing travel history; surveying signs and indications of RTI; recording patients' body temperature level while arriving at clinics; getting mouth flushed with $1 \%$ hydrogen peroxide before beginning of any technique or treatment procedures ; utilizing an elastic dam and high volume pull during process; and often cleaning and sanitizing open contact territories including dental chairs, entryway handles, seats and, washrooms in the clinics and hospitals. In spite of the fact that the IDA has distributed preventive rules, most of dental specialists are yet hesitant and having fear of treating patients (Source IDA-COVID-19 Resources for Dentists). Actually, most dental specialists may not know about the ongoing rules and secured guidelines to be adopted during treatment of their patients. Hence we have initiated a poll based examination to assess dental specialist attitude and approach towards clinical practices in India. Truth is to be told, most dental specialists may not know about the ongoing rules. The current study expected to understand anxiety and fear of getting infected among dental specialists while working at their clinics or hospitals during the current viral pandemic Covid 19.

\section{Objective of Study:}

The objective of study is to understand anxiety and fear level of dentists getting infected while working in their clinics, during the treatment or checkups of the patients arriving in current corona virus (COVID-19) outbreak. In addition, also to study their awareness and knowledge about precautions and practice modifications required and needed while treatment procedures to remain safe and secured to combat COVID-19 pandemic efficiently.

\section{Methodology:}

The current cross-sectional study was directed by an online survey from 3rd Aug to 8th Sept 2020. For majority from central region of the country, a very much developed survey was planned at google doc.

The survey form was circulated through online social media and an email to dental experts to collect their responses through an online well defined questionnaires. All paramedical staff and dental science undergraduate students were excluded from this study.

The questionnaire survey contained an aggregate of 24 questions for submissions, which were divided into two areas. The principal area zeroed in on the threat among dental specialists about getting infected with COVID-19 viral infection and the subsequent segment was intended to assemble data about their clinical practice alterations adopted or made to overcome and fight reducing COVID-19 spread as per IDA practice rules.

A sum of 210 members from 16 states wherein majority 153 dental practitioners responded are from Madhya Pradesh India over took and submitted the survey, barring 29 unfilled 
or incompletely filled structures (Figure 1). The study expected to understand anxiety and fear of getting infected among dental specialists working during the current viral scenario while treating their patients. Likewise, dental specialist information about different practice changes adopted to battle the novel Corona outbreak (COVID-19) has been assessed.

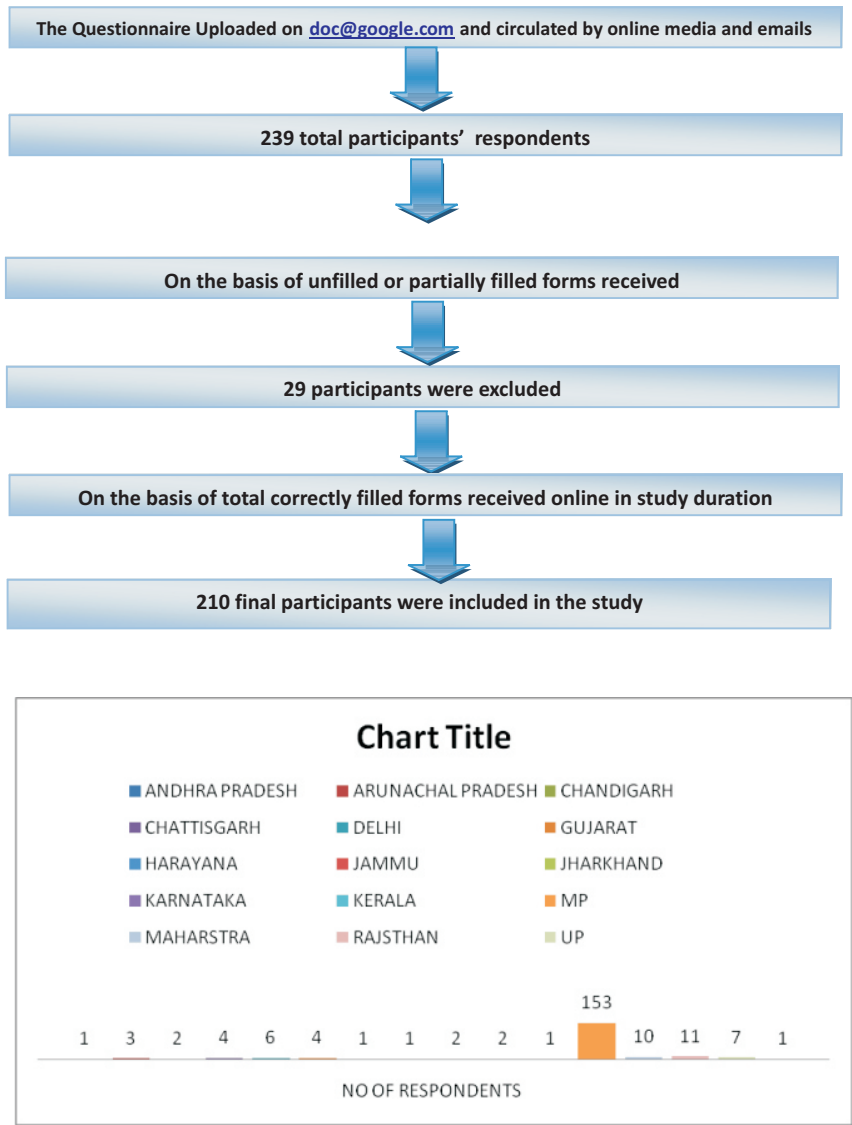

Chart - 1 : No of Respondents

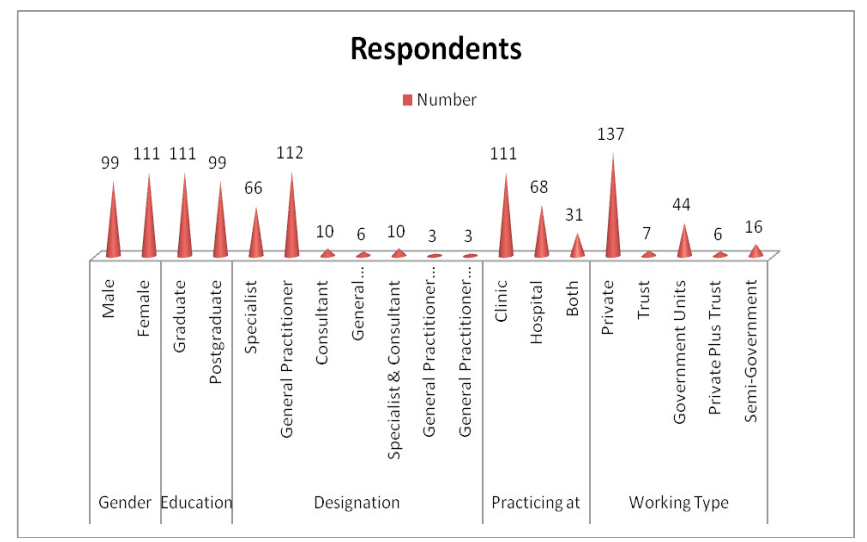

Chart -2 : Demographic Classification of Dental Care Professionals $(\mathrm{n}=210)$
Table-1: Demographic Classification of Dental Care Professionals $(\mathrm{n}=210)$

\begin{tabular}{|l|l|l|}
\hline Demographics & Particulars & Number \\
\hline Gender & Male & $99(47.1 \%)$ \\
\cline { 2 - 3 } & Female & $111(52.9 \%)$ \\
\hline \multirow{4}{*}{ Education } & Graduate & $111(52.9 \%)$ \\
\cline { 2 - 3 } & Postgraduate & $99(47.1 \%)$ \\
\cline { 2 - 3 } & Specialist & $66(31.4 \%)$ \\
\cline { 2 - 3 } & General Practitioner & $112(53.3 \%)$ \\
\cline { 2 - 3 } & Consultant & $10(4.8 \%)$ \\
\cline { 2 - 3 } & General Practitioner, Specialist \& Consultant & $6(2.9 \%)$ \\
\cline { 2 - 3 } & Specialist \& Consultant & $10(4.8 \%)$ \\
\cline { 2 - 3 } & General Practitioner \& Consultant & $3(1.4 \%)$ \\
\cline { 2 - 3 } & General Practitioner \& Specialist & $3(1.4 \%)$ \\
\hline \multirow{5}{*}{ Practicing at } & Clinic & $111(52.9 \%)$ \\
\cline { 2 - 3 } & Hospital & $68(32.3 \%)$ \\
\cline { 2 - 3 } & Both & $31(14.8 \%)$ \\
\hline Working Type & Private & $137(65.2 \%)$ \\
\cline { 2 - 3 } & Trust & $7(3.3 \%)$ \\
\cline { 2 - 3 } & Government Units & $6(2.9 \%)$ \\
\cline { 2 - 3 } & Private Plus Trust & $16(7.6 \%)$ \\
\cline { 2 - 3 } & Semi-Government & \\
\hline
\end{tabular}

The above table exhibits the demographic information of Dental care Professionals. The data reveals that out of 210 Professionals, $47.1 \%$ were male and $52.9 \%$ were female. Regarding education it is found that $52.9 \%$ were Graduates and $47.1 \%$ were pgs. As Designation is concerned, 31.4 are practicing as Specialist, $53.3 \%$ are practicing as General Practitioners, $4.8 \%$ are Consultants, $2.9 \%$ are practicing as General Practitioner, Specialist \& Consultant, $4.8 \%$ are both Specialist \& Consultant, $1.4 \%$ are General Practitioner \& Consultant and again $1.4 \%$ are practicing as General Practitioner \& Specialist. Regarding the workplace, it is found that $52.9 \%$ are practicing at their own clinics, $32.3 \%$ are working at Hospitals and $14.8 \%$ are practicing at both Clinic \& Hospitals. In consideration with the working type Institutions, it reveals that $65.2 \%$ are from private working type, $3.3 \%$ are from Trust, $21 \%$ are from Government Units, $2.9 \%$ are from Private plus Trust and rest $7.6 \%$ are from Semi Government Units.

Table-2: Assessment on Fear or Afraid of Dental Care professionals $(\mathrm{n}=210)$

\begin{tabular}{|l|l|l|l|}
\hline Statement & Yes & No & Not Sure \\
\hline $\begin{array}{l}\text { Are you afraid or concerned about getting } \\
\text { Infected with COVID-19 from a Patient } \\
\text { visiting and Co-Worker working at your } \\
\text { clinic in this outbreak covid19? }\end{array}$ & $145(69 \%)$ & $30(14.3 \%)$ & $35(16.7 \%)$ \\
\hline $\begin{array}{l}\text { Are you scared while providing check-up } \\
\text { or Treatment to a patient who visited your } \\
\text { clinic who is coughing or can be suspected } \\
\text { of being Infected with COVID-19? }\end{array}$ & $157(74.8 \%)$ & $27(12.9 \%)$ & $26(12.4 \%)$ \\
\hline $\begin{array}{l}\text { Do you feel suggest or think not to do } \\
\text { Practice and open clinic until the number of } \\
\text { COVID-19 patient cases starts reducing in } \\
\text { your region or locality? }\end{array}$ & $99(47.1 \%)$ & $110(52.4 \%)$ & $1(.5 \%)$ \\
\hline
\end{tabular}


University J Dent Scie 2020; Vol. 6, Issue 3

\begin{tabular}{|l|l|l|l|}
\hline $\begin{array}{l}\text { Do you practice at multiple locations and } \\
\text { units? }\end{array}$ & $62(29.5 \%)$ & $148(70.5 \%)$ & 0 \\
\hline $\begin{array}{l}\text { Do you feel or get nervous and cautious } \\
\text { when talking to patients in close vicinity } \\
\text { while procedures and treatments or } \\
\text { consultations? }\end{array}$ & $114(54.3 \%)$ & $70(33.3 \%)$ & $26(12.5 \%)$ \\
\hline $\begin{array}{l}\text { Do you have fear or threat that you could } \\
\text { carry the Infection from your clinic or } \\
\text { hospital back to your home and can get } \\
\text { Family infected? }\end{array}$ & $170(81 \%)$ & $16(7.6 \%)$ & $24(11.4 \%)$ \\
\hline $\begin{array}{l}\text { Are you afraid of getting quarantined if get } \\
\text { Infected }\end{array}$ & $84(40 \%)$ & $64(30.5 \%)$ & $62(29.5 \%)$ \\
\hline $\begin{array}{l}\text { Are you curious about the cost of treatment } \\
\text { on the off chance that you get Infected? }\end{array}$ & $125(59.5 \%)$ & $36(17.1 \%)$ & $49(23.3 \%)$ \\
\hline
\end{tabular}

In above table description of the fear and anxiety levels of dental care professionals towards COVID-19 is given; $69 \%$ of participants were afraid concerned about getting Infected with Corona Virus spread from a patient visiting or coworker at their clinic in this outbreak. $74.8 \%$ were scared while providing check-up or treatment to patients who visited their clinic who were coughing or can be suspected of being infected with corona virus infection. $47.1 \%$ of participants felt suggest or think not to do practice and open clinic until the number of COVID-19 patient cases starts reducing in the region or locality, Among these respondents $29.5 \%$ were practicing at multiple locations and units. $54.3 \%$ participants felt or get anxiety and scared while talking to patients in close vicinity while procedures and treatments or consultations, $81 \%$ professionals have fear or threat that they could carry the infection from clinic or hospital back to their home and can get their family infected. $40 \%$ were afraid of getting quarantined if get Infected and 59.5\% were curious about the cost of treatment to be incurred on the off chance that you get Infected.

Table -3: Knowledge \& Awareness of Suggestive Measures $(\mathrm{n}=210)$

\begin{tabular}{|l|l|l|l|}
\hline \multicolumn{1}{|c|}{ Statement } & \multicolumn{1}{c|}{ Yes } & No & Not Sure \\
\hline $\begin{array}{l}\text { Are you updated with the WHO } \\
\text { guidelines for cross-Infection } \\
\text { control in context to COVID-19? }\end{array}$ & $189(90 \%)$ & $5(2.4 \%)$ & $16(7.6 \%)$ \\
\hline $\begin{array}{l}\text { Are you right now asking each } \\
\text { patient's travel history or any event } \\
\text { of infection recently before } \\
\text { performing treatment? }\end{array}$ & $200(95.2 \%)$ & $10(4.8 \%)$ & $0(0 \%)$ \\
\hline $\begin{array}{l}\text { Are you checking the patient's body } \\
\text { temperature and using oximeter } \\
\text { before giving Dental Treatment? }\end{array}$ & $199(95.8 \%)$ & $11(5.2 \%)$ & $0(0 \%)$ \\
\hline $\begin{array}{l}\text { Do you avoid/ignore the treatment } \\
\text { of patients showing suspicious } \\
\text { symptoms? }\end{array}$ & $155(73.8 \%)$ & $32(15.2 \%)$ & $23(11 \%)$ \\
\hline $\begin{array}{l}\text { Do you think the surgical mask is } \\
\text { sufficient to prevent Infection of } \\
\text { COVID 19? }\end{array}$ & $13(6.2 \%)$ & $159(75.7 \%)$ & $38(18.1 \%)$ \\
\hline $\begin{array}{l}\text { Do you think N-95 mask ought to } \\
\text { be worn in Dental Practice because } \\
\text { of the outbreak? }\end{array}$ & $171(81.4 \%)$ & $16(7.6 \%)$ & $23(11 \%)$ \\
\hline
\end{tabular}

\begin{tabular}{|l|l|l|l|}
\hline $\begin{array}{l}\text { Have you ever worn an N-95 mask, } \\
\text { PPE kit, and other suggestive } \\
\text { accessories while treating a patient } \\
\text { in your Dental Practice? }\end{array}$ & $185(88.1 \%)$ & $21(10 \%)$ & $4(1.9 \%)$ \\
\hline $\begin{array}{l}\text { Do you follow prescribed } \\
\text { precautions of avoidance of } \\
\text { infection from or for every patient } \\
\text { in routine? }\end{array}$ & $201(95.7 \%)$ & $9(4.3 \%)$ & $0(0 \%)$ \\
\hline $\begin{array}{l}\text { Do you use rubber dam Isolation } \\
\text { for every patient? }\end{array}$ & $37(17.6 \%)$ & $153(72.9 \%)$ & $20(9.5 \%)$ \\
\hline $\begin{array}{l}\text { Do you wash hands with soap /use } \\
\text { sanitizer before and after the } \\
\text { treatment of every patient? }\end{array}$ & $207(98.5 \%)$ & $2(1 \%)$ & $1(.5 \%)$ \\
\hline $\begin{array}{l}\text { Do you ask the patient to rinse } \\
\text { his/her mouth with anti-bacterial } \\
\text { mouthwash before treatment and in } \\
\text { between procedures? }\end{array}$ & $190(90.5 \%)$ & $14(6.7 \%)$ & $6(2.9 \%)$ \\
\hline $\begin{array}{l}\text { Are you aware of whom \& where to } \\
\text { connect or contact if you come } \\
\text { across a patient or contact with } \\
\text { suspected COVID-19 Infection } \\
\text { during your work? }\end{array}$ & $193(91.9 \%)$ & $17(18.1 \%)$ & $0(0 \%)$ \\
\hline
\end{tabular}

The above table reflects the description of the knowledge and awareness of dental care professionals about COVID-19 clinical practice procedures; $90 \%$ were updated with the WHO guidelines for cross-Infection control in context to COVID-19, 95.2\% preferred asking each patient's travel history or any event of infection recently before performing treatment, $73.8 \%$ were ignored the treatment of patients showing suspicious symptoms, only $6.2 \%$ participants thought that the surgical mask is sufficient to prevent Infection of COVID 19. Accordingly, $81.4 \%$ responded that N-95 mask ought to be worn in Dental Practice because of the outbreak, 88.1\% participants worn an N-95 mask, PPE kit, and other suggestive accessories while treating a patient in their clinics , 95.7\% professionals followed prescribed precautions of avoidance of infection from or for every patient in routine, only $17.6 \%$ professionals used rubber dam Isolation for every patient, $98.5 \%$ washed hands with soap /use sanitizer before and after the treatment of every patient, $90.5 \%$ participants asked the patient to rinse his/her mouth with anti-bacterial mouthwash before treatment and in between procedures and $91.9 \%$ were aware of whom \& where to connect or contact if they come across a patient or contact with suspected COVID-19 Infection during their clinical practice and treatment of patients.

\section{Testing of Hypotheses:}

H01: There is no significant association between gender and the level of fear and threat of doctors while treating patients in clinic during this Corona covid 19 Pandemic.

H01a: There is no significant association between gender and afraid or concerned about getting infected with COVID-19 from a patient visiting and co-worker working at clinic in this outbreak covid[19]. 


\section{Anxiety Responses}

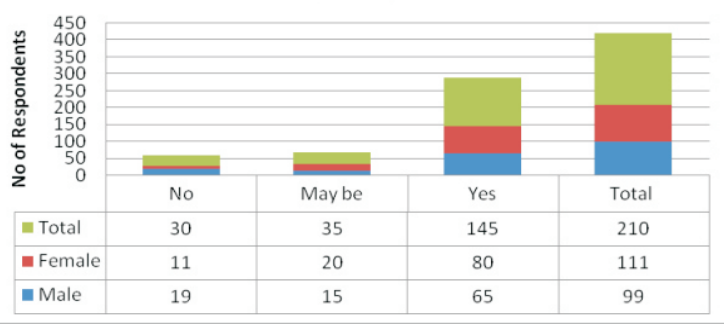

Chart -3: Anxiety Level In Male and Female

Table -4 :Anxiety* Gender cross tabulation count

\begin{tabular}{|l|l|l|l|l|}
\hline \multicolumn{2}{|c|}{ Responses } & Gender & Total \\
\cline { 3 - 4 } \multicolumn{2}{|c|}{} & Male & Female & \\
\hline \multirow{4}{*}{ A1 } & No & 19 & 11 & 30 \\
\cline { 2 - 5 } & May be & 15 & 20 & 35 \\
\cline { 2 - 5 } & Yes & 65 & 80 & 145 \\
\hline Total & 99 & 111 & 210 \\
\hline
\end{tabular}

Table-4.1: Chi-Square Tests Afraid \& Gender

\begin{tabular}{|c|l|l|l|}
\hline & \multicolumn{1}{|c|}{ Value } & Df & $\begin{array}{c}\text { Asymp. Sig. (2- } \\
\text { sided) }\end{array}$ \\
\hline Pearson Chi-Square & $3.726^{\mathrm{a}}$ & 2 & 0.155 \\
\hline Likelihood Ratio & 3.745 & 2 & 0.154 \\
\hline $\begin{array}{c}\text { Linear-by-Linear } \\
\text { Association }\end{array}$ & 2.406 & 1 & 0.121 \\
\hline N of Valid Cases & 210 & & \\
\hline
\end{tabular}

A. 0 cells $(0.0 \%)$ have expected count less than 5 . The minimum expected count is 14.14 .

The calculated value of chi-square test (3.726) is lesser than the table value of chi-square (9.210) for 2 degrees of freedom at $.155>0.01$ level of insignificance. As calculated p-value is higher than 0.01 so the framed hypothesis for this purpose is accepted. Therefore, it could be concluded that there is no significant association between Gender and anxiety or concerned about getting infected with COVID-19 from a Patient visiting and Co-Worker working at clinic in this outbreak covid19. Both male and female perceives equally about getting infected with COVID-19 from a patient visiting and co-Worker working at clinic in this outbreak covid 19.

$\mathrm{H} 01 \mathrm{~b}$ : There is no significant association between gender and anxiety while providing check-up or treatment to a patient who visited clinic who is coughing or can be suspected of being infected with COVID-19.

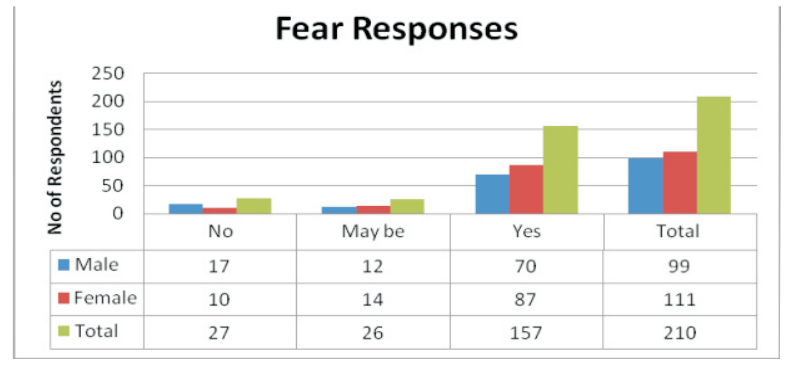

Chart-4: Fear Responses Count
Table -5:Fear * Gender $\quad$ Cross tabulation Count

\begin{tabular}{|l|l|l|l|l|}
\hline \multirow{2}{*}{ Responses } & \multicolumn{2}{|c|}{ Gender } & Total \\
\cline { 3 - 5 } \multicolumn{2}{|c|}{} & Male & Female & \\
\hline \multirow{4}{*}{ A12 } & No & 17 & 10 & 27 \\
\cline { 2 - 5 } & May be & 12 & 14 & 26 \\
\cline { 2 - 4 } & Yes & 70 & 87 & 157 \\
\hline Total & 99 & 111 & 210 \\
\hline
\end{tabular}

Table-5.1:Chi-Square Tests Fear * gender

\begin{tabular}{|c|l|l|l|}
\hline & \multicolumn{1}{|c|}{ Value } & \multicolumn{1}{c|}{ Df } & \multicolumn{1}{|c|}{ Asymp. Sig. (2-sided) } \\
\hline Pearson Chi-Square & $3.134^{\mathrm{a}}$ & 2 & 0.209 \\
\hline Likelihood Ratio & 3.148 & 2 & 0.207 \\
\hline $\begin{array}{c}\text { Linear-by-Linear } \\
\text { Association }\end{array}$ & 2.649 & 1 & 0.104 \\
\hline N of Valid Cas es & 210 & & \\
\hline
\end{tabular}

0 cells $(0.0 \%)$ have expected count less than 5 .

The minimum expected count is 12.26 .

The calculated value of chi-square test (3.134) is lesser than the table value of chi-square (9.210) for 2 degrees of freedom at .209>0.01 level of insignificance. As calculated p-value is higher than 0.01 so the framed hypothesis for this purpose is accepted. Therefore, it could be concluded that there is no significant association between gender and fear while providing check-up or treatment to a patient who visited clinic who is coughing or can be suspected of being infected with COVID-19. Both male and female perceive equal fear while providing check-up or treatment to a patient who visited clinic who is coughing or can be suspected of being infected with COVID-19.H02: There is no significant association between Gender and the awareness of whom \& where to connect or contact if they come across a patient or contact with suspected COVID-19 Infection during work.

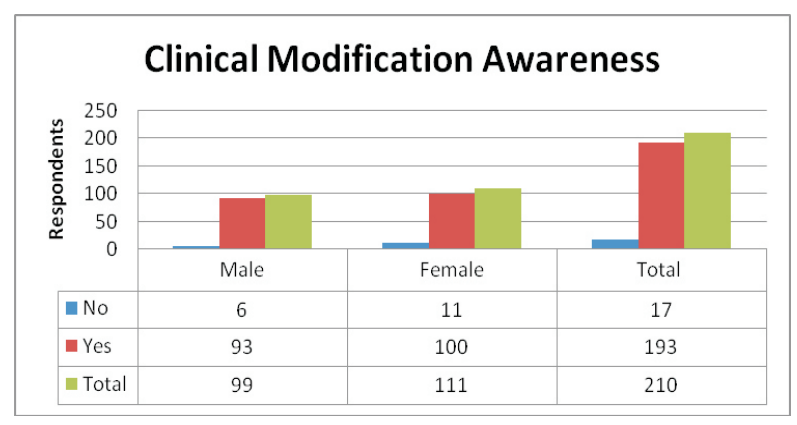

Chart -5:Awareness * gender Cross tabulation Count

\begin{tabular}{|c|c|c|c|c|}
\hline \multicolumn{2}{|c|}{} & \multicolumn{2}{|c|}{ Gender } & \multirow{2}{*}{ Total } \\
\cline { 3 - 4 } \multicolumn{2}{|c|}{} & Male & Female & \\
\hline \multirow{2}{*}{ Awareness } & $N_{0}$ & 6 & 11 & 17 \\
\cline { 2 - 4 } & Yes & 93 & 100 & 193 \\
\hline \multicolumn{2}{|c|}{ Total } & 99 & 111 & 210 \\
\hline
\end{tabular}

Table-6:Awareness * gender Cross tabulation Count 
University J Dent Scie 2020; Vol. 6, Issue 3

Table -6.1: Chi-Square Tests
\begin{tabular}{|c|l|l|l|l|l|}
\hline & Value & Df & $\begin{array}{l}\text { Asymp. Sig. } \\
(2-\text { sided })\end{array}$ & $\begin{array}{l}\text { Exact Sig. (2- } \\
\text { sided) }\end{array}$ & $\begin{array}{l}\text { Exact Sig. (1- } \\
\text { sided) }\end{array}$ \\
\hline Pearson Chi-Square & $1.042^{\mathrm{a}}$ & 1 & 0.307 & & \\
\hline Continuity Correction $^{\mathrm{b}}$ & 0.589 & 1 & 0.443 & & \\
\hline Likelihood Ratio & 1.06 & 1 & 0.303 & & \\
\hline Fisher's Exact Test & & & & 0.448 & 0.222 \\
\hline $\begin{array}{c}\text { Linear-by-Linear } \\
\text { Association }\end{array}$ & 1.037 & 1 & 0.308 & & \\
\hline N of Valid Cases & 210 & & & & \\
\hline
\end{tabular}

0 cells $(0.0 \%)$ have expected count less than 5 .

The minimum expected count is 8.01 . Computed only for a $2 \times 2$ table

The calculated value of chi-square test $(1,042)$ is lesser than the table value of chi-square (6.635) for 2 degrees of freedom at $307>0.01$ level of insignificance. As calculated p-value is higher than 0.01 so the framed hypothesis for this purpose is accepted. Therefore, it could be concluded that there is no significant association between Gender and the awareness of whom $\&$ where to connect or contact if they come across a patient or contact with suspected COVID-19 Infection during work. The result indicated that both male and female are equally aware of whom \& where to connect or contact if they come across a patient or contact with suspected COVID-19 Infection during work.

\section{Conclusion:}

Despite having sufficient awareness and knowledge about the procedures and clinical practices, Dental practitioners are in a state of anxiety and fear while treating their patients due to the COVID-19 pandemic spread and opening of lockdown despite having increasing number of patients impacted by novel corona virus. Currently, the effects of COVID-19 are worsening day by day in community as a viral spread. Which makes them scared and in anxiety about their becoming prone to get infected from visiting patients and co workers daily in the clinic either at private clinics or in hospitals. Several dental practitioners have modified their services according to recommended guidelines but for only emergency treatment or for the patients whom they are treating are under process, or closed down practices for an uncertain period awaiting for the decline in number of patients which is increasing day by day . It is essential that in the present scenario, priority is to be given to dental procedures modifications and take utmost caution and follow measures given by the WHO and Dental or Medical Council of India .All dental treatments are to be done under strict guidelines and precautions practitioners could take safely while treating a patient visiting the clinic for clinical procedures or treatments till the time the vaccine arrives or there is a drop in count of people getting covid- 19

positive in community spread.. This would be an appropriate step in attempts to curtail the further spread of COVID-19 and dental practitioners to stay safe and secured also keeping their families safe and uns infected with their professional challenges.

\section{References:}

1. Gralinski, L.E.; Menachery, V.D. Return of the corona virus: 2019-ncov. Viruses 2020, 12, 135.

2. Neher, R.A.; Dyrdak, R.; Druelle, V.; Hodcroft, E.B.; Albert, J. Potential impact of seasonal forcing on asarscov-2 pandemic. Swiss Med. Wkly. 2020, 150, w20224.

3. Khurshid, Z.; Asiri, F.Y.I.;Wadaani, H. Al Human Saliva: Non-Invasive Fluid for Detecting Novel Corona virus(2019-ncov). Int. J. Environ. Res. Public Health 2020, 17, 2225.

4. Zu, Z.Y.; Jiang, M.D.; Xu, P.P.; Chen,W.; Ni, Q.Q.; Lu, G.M.; Zhang, L.J. Corona virus Disease 2019 (COVID19):A Perspective from China. Radiology 2020, 200490.

5. Chen, Y.; Liu, Q.; Guo, D. Emerging corona viruses: Genome structure, replication, and pathogenesis.J. Med. Virol. 2020, 92, 418-423.

6. Peng, X.; Xu, X.; Li, Y.; Cheng, L.; Zhou, X.; Ren, B. Transmission routes of 2019-ncov and controls in dental practice. Int. J. Oral Sci. 2020, 12, 1-6. [crossref]

7. Backer, J.A.; Klinkenberg, D.;Wallinga, J. Incubation period of 2019 novel corona virus (2019-ncov) infections among travelers from Wuhan, China, 20-28 January 2020. Euro Surveill. 2020, 25.

8. Guan, W.; Ni, Z.; Hu, Y.; Liang, W.; Ou, C.; He, J.; Liu, L.; Shan, H.; Lei, C.; Hui, D.S.C.; et al.Clinical Characteristics of Corona virus Disease 2019 in China. N. Engl. J. Med. 2020.

9. Corman, V.M.; Landt, O.; Kaiser, M.; Molenkamp, R.; Meijer, A.; Chu, D.K.; Bleicker, T.; Brünink, S.;Schneider, J.; Schmidt, M.L.; et al. Detection of 2019 novel corona virus (2019-ncov) by real-time RTPCR.Euro Surveill. 2020, 25, 1-8.

10. Zhang, L.; Liu, Y. Potential interventions for novel corona virus in China: A systematic review. J. Med. Virol.2020, 479-490.

11. Wu, P.; Hao, X.; Lau, E.H.Y.;Wong, J.Y.; Leung, K.S.M.;Wu, J.T.; Cowling, B.J.; Leung, G.M. Realtime tentative assessment of the e p i d e m i o 1 o g i c a $l$ characteristics of novel corona virus infections in Wuhan, China, as at 22 January 2020. Euro Surveill. 2020, 25, 1-6. 